\section{SOI: 1.1/TAS DOI: 10.15863/TAS International Scientific Journal Theoretical \& Applied Science}

\author{
p-ISSN: 2308-4944 (print) e-ISSN: 2409-0085 (online) \\ Year: $2018 \quad$ Issue: 09 Volume: 65
}

Published: 01.09.2018～http://T-Science.org

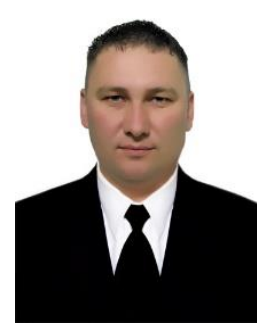

K. I. Kurpayanidi

$\mathrm{Ph} \mathrm{D}$ in economics,

professor of the Russian academy

of natural sciences,

Fergana polytechnic institute,

Fergana, Uzbekistan

Corresponding member of the

International Academy of

Theoretical \& Applied Sciences

w7777@mail.ru

ORCID - 0000-0001-8354-1512

SECTION 31. Economic research, finance, innovation, risk management.

UDC 334.722

\title{
QUESTIONS OF CLASSIFICATION OF INSTITUTIONAL CONDITIONS, DETERMINING THE STRUCTURE OF BUSINESS MANAGEMENT IN UZBEKISTAN
}

Abstract: The article deals with classical problems in determining institutional conditions, the formation of a competitive business environment, and the conduct of private business. During the analysis, the author identified the problems of forming a business environment. On the basis of this, the directions of increasing business activity of business entities in the Republic of Uzbekistan are proposed.

Key words: business environment, institutional environment, infrastructure, classification, entrepreneurship, business structure, Strategy of economic development of Uzbekistan.

Language: English

Citation: Kurpayanidi KI (2018) QUESTIONS OF CLASSIFICATION OF INSTITUTIONAL CONDITIONS, DETERMINING THE STRUCTURE OF BUSINESS MANAGEMENT IN UZBEKISTAN. ISJ Theoretical \& Applied Science, 09 (65): 1-8.
Soi: http://s-o-i.org/1.1/TAS-09-65-1
Doi: crossef https://dx.doi.org/10.15863/TAS.2018.09.65.1

\section{Introduction}

Institutional conditions for the formation of small business should be perceived as a set of rules and mechanisms forcing small business to the implementation of these established rules and norms. Even insignificant dynamics of the institutional structure affect significant, if not decisive impact on subsystems, including number and on business structures [1]. Institute, rules, special guarantors of rules are mandatory elements of institutional conditions in formation of small business.

There are radical macroeconomic transformations in modern Uzbekistan, the ultimate goal of which is the implementation of transition to an open socially-oriented market economy. Thereby the structure of business is changing under the influence of resource, conjuncture and institutional factors.

\section{Analysis of the literature on the topic}

Fundamental moments of the theory of entrepreneurship, small business in the conditions of institutional transformations are stated in the works of known foreign economists J. Galbraith [2], D. Deakins [3], P. Drucker [4], A. Marshall [5], A. Smith [6], B. Santo [7], K. Tateisi [8], A. Hosking
[9], J. Schumpeter [10] etc. Among the most important studies that illuminate certain aspects of development of small business in the CIS, it is necessary to note such authors, as L. Abalkin [11], V. Avtonomov [12], A. Blinov [13], T. Koichuev [14], O. Krivoruchko [15], M. Lapusta [16], A. Orlov [17], E. Primov [18], V. Rube [19], F. Shakhmalov [20], A. Yudanov [21] and others.

The peculiarities of the formation and development of this sector of the economy were the investigations of A. Khikmatov [22], B. Berkinov, M. Ikramov[23], N. Mahmudov, M. Tursunkhodzhaev, Z. Hudayberdiyev, V. Baturina, D. Trostyansky and others.

Directly to the development of small business and private entrepreneurship in new institutional settings were devoted the dissertation works of A.Akhmediyeva, U. Validzhanova, O. Ismailov, L. Ishmukhamedova, S. Salaev, I.Tursunov, E.Ergashev, M.Eshov and others. The main focus was on regional or sectoral aspects of the solution of this problem. However, the areas of research for the problem for the last time has changed somewhat from analyzing common problems of small business (place and role in the economic system, in solving social problems, employment problems, etc.) to the 
analysis of the reasons constraining its development and search of conditions activation of small business. At the same time, practice shows that despite all efforts to activate small business from the government side at various levels from national to regional, there is no need to discuss about a radical improvement in the situation. This is explained as the multifaceted nature of the phenomenon of small business, and the variety of conditions for its functioning. Therefore, despite a large number of publications, devoted to various aspects of small business, the research of the problem requires further development. In particular, institutional conditions that determine the structure of entrepreneurship in Uzbekistan has hardly been investigated.

\section{Research Methodology}

Instrument-methodical research apparatus is based on application, within the framework of the system approach, general scientific methods of research: logical and situational analysis, expert assessments, questionnaires, observation, interviewing, groupings, comparison. These tools have been used in various combinations at different stages of the research, which allowed to ensure the scientific reliability of the final results, conclusions and recommendations.

\section{Analysis and Results}

In 2016, a number of systemic measures were taken to create conditions for doing business, attraction of foreign investments for small and private entrepreneurship, which are the basis of development of the economy of Uzbekistan. In October 2016, the President of the Republic of Uzbekistan Sh. Mirziyoyev issued a Decree "On additional measures for ensuring the accelerated development of entrepreneurial activity, all-round protection of private property and quality improvement of business climate "[24], aimed at creating an even more favourable business environment by eliminating all types of unscheduled, counter checks and removal of barriers. Particular attention in this document is given to the adoption of the effective measures to ensure the dynamic modernization of small enterprises and to stimulate their export activities, which should become the main direction of economic growth in the development of industries and regions, ensuring employment of the population, as well as additional measures on further stimulating the participation of small business and private entrepreneurship in exports.

In accordance with the Decree of the President of the Republic of Uzbekistan "On measures to radical improvement of the system of state protection of legitimate interests of business and further development of entrepreneurship" dated June 19 2017 [25], as well as the Resolution "On the improvement of the organization activities of the Chamber of Commerce and Industry of the Republic of Uzbekistan "[26] a profound reform of the activities of the Chamber of Commerce and Industry is carried out through a review of its tasks, functions and powers.

Implementation of measures to ensure reliable protection of private interests of small business contributed in 2016 to a dynamic development of this sector. Added cost of products of small entrepreneurship in the country's gross domestic product during the year grew and amounted to: $43.1 \%$ - in the I quarter, $46.0 \%$ - in the II quarter, $54.6 \%$ - in the III quarter and by the end of the year it reached $56.9 \%$, exceeding by 0.4 percentage point to the level of 2015. During the year an increase in the share of small business in GRP of Jizzak (from $61.6 \%$ in the first quarter to $80.3 \%$ by the end of the year), Namangan (from $68.2 \%$ to $80.3 \%$ ), Samarkand (from $67.7 \%$ to $78.0 \%$ ), as well as in the Surkhandarya, Khorezm, Syrdarya, Bukhara and Andijan regions [27].

In 2016 structural changes in small business intensified in the direction of growth in the share of industrial products, paid services and retail turnover, which increased to $72.9 \%$. Decreased the share of agriculture, forestry and fisheries and construction works to $27.0 \%$, as well as agriculture from $20.9 \%$ (I quarter) to $18.8 \%$ (by the end of the year) and construction works, respectively, from 9.4 to $8.2 \%$.

At the end of 2016, the number of people employed in small business amounted to 10392.5 thousand people against 10178.9 thousand people in 2015 (growth of 2.1 percentage points).

Institutional support of business entities in the past year has been marked by a significant increase in lending. So, allocated loans of about 16 trillion UZS, with 1.3 times growth by 2015, including 3.3 trillion UZS microcredits. Measures taken to form a business environment, comprehensive support and further stimulation of development small business and private entrepreneurship contributed to the creation of about 32000 new small business entities in 2016. As a result, the share of small business in GDP increased to $56.9 \%$ (56.5\% in 2015), in industry up to $45 \%(40.6 \%)$, in investments up to $40.3 \%$ (36.3\%) and in employment to $78.1 \%(77.9 \%)$.

Based on the studies carried out, it is possible to determine the nature of changes of these factors and the specific features of their influence on various structural characteristics of business (table 1). 
Factors and structural characteristics of business

Table 1

\begin{tabular}{|c|c|c|c|}
\hline Type of factor & $\begin{array}{c}\text { Time lag impacts on } \\
\text { structural } \\
\text { indicators }\end{array}$ & $\begin{array}{c}\text { Structural } \\
\text { characteristics, } \\
\text { most highly dependent } \\
\text { from this factor }\end{array}$ & Type of change \\
\hline Institutional factors & Significant. positive & $\begin{array}{c}\text { The form property, scale } \\
\text { of business, volumes of } \\
\text { loans and } \\
\text { investments, intensity and } \\
\text { forms cooperation of small } \\
\text { and big business }\end{array}$ & $\begin{array}{c}\text { Slow for basic formal } \\
\text { rules, socially rooted } \\
\text { Informal institutions. } \\
\text { formal regulations }\end{array}$ \\
\hline Conjuncture factors & Close to zero & $\begin{array}{c}\text { The volume of loans, } \\
\text { amount investment, the } \\
\text { number employed, }\end{array}$ & Rapid \\
\hline Resource factors & Positive, small & Industry & Slow \\
\hline
\end{tabular}

Among the many factors that influence the results of production and economic activity, a special role belongs to institutional factors. Currently, the most relevant is the treatment of the winner of the Nobel Prize in economics of 1993 "For the revival of research in the field of economics, thanks to application to them of economic theory and quantitative methods, allowing to explain economic and institutional changes" Douglass Cecil North. D. North notes the importance of various institutions in the historical context, he considered economic development of countries of Europe and the United States in the context of the industrial revolution. Based on this he puts into the concept of the institution "the rules of the game in society or more formally, created by people constraints, forming people interaction"[28]. Institution conditions is meant as a stable complex formal (laws) and informal (contracts and voluntarily accepted codes of conduct) of rules, principles and norms, as well as coercive factors, structuring their interaction.

There is no specific idea in the former Soviet countries as to which institutions are needed for the successful establishment of a market economy, how they are interrelated, ignoring legal, economic, as well as moral and ethical psychological basis of their formation[29]. This led to predominantly discrete, point-like nature of institutional transformations, many of which did not contribute to economic growth, as they did not justify.

In our opinion, especially in the conditions of transformation of socio-economic systems that the problem of institutional transformations acquires a special significance, not yielding to the financial stabilization.

Thus the state can adhere to two strategies of behaviour:

- promote the organization of these institutions;

- directly establish these institutions.
At the same time, public institutions, such as legal ones, belong to the sphere of government activity. Quasi-public, institutions of financial sphere, in the field of accounting and insurance, may transferred to the private sector. Institutional environment of small entrepreneurship is determined on the basis of a set of institutional conditions. It includes the most common political, economic, and social rules, on the basis of which the limits of norms, functioning and behaviour of small business entities are built. For rational formation of a set of institutional conditions, knowledge is necessary essence and specificity of each of them, take into account their existing structural co-ordination. The resulting classification can vary according to the criteria included in the review.

It is proposed to distinguish between the institutional conditions of direct and indirect influence. The first force small businesses to be based on the instructions of the government, and not on an independent economic choice when making decisions. The most striking example is the fiscal tools, as well as well-known volume requirements depreciation charges. These environmental conditions are characterized by high efficiency, as the economic result is achieved operatively. At the same time, they have a number of shortcomings. It should be noted that many different entities operate in the economy, as a result which forms a certain system of connections between them. As soon as the state imposes a specific decision, the consequence is the emergence of a reaction to it, even in those agents of the market, on which state measures were not directed. Consequently, the already existing equilibrium between market participants will be violated, and, therefore, it can be argued that the institutional conditions of direct impact can disrupt the natural development of market processes. In contrast to the institutional conditions that have been already, considered direct effects do not violate the 
market situation. Their essence lies in the fact that the process of decision-making by the entrepreneurship entities, state does not have direct intervention. His task is to create a set of prerequisites so that the entities in case of independent choice of rules of action, such options considered as the most expedient, which correspond to the goals of economic politics. It is advisable to note that a temporary interval between the moment when the state takes measures and reacts to them economy with subsequent changes in the results of management.

In addition to this, it should be noted that indirect measures are characterized by heterogeneity in terms of the degree of influence on the acceptance by entrepreneurship entities of independent solutions. Due to the fact that concepts "institution" and "institutional conditions" are inseparable, we should single out the most fundamental, forming institutions, and then consider classification of the analysed conditions on their basis. According to the results the first group is represented by power and political institutions, which include the executive and legislative power; second - economic institutions that contain financial and taxation systems, business institutions, its infrastructure support; third group includes the ideological institutions that determine the motivation for initiative activity, culture of business relations, system of values. Based on the classification of the main institutions, we will understand that administrative conditions institutional conditions of first group, and about the economic and ideological, respectively, the second and the third.

Do not ignore the range of problems that are solved through favorable institutional conditions [30, 31].

Classifying according to this feature, we distinguish the following species of institutional conditions (Fig. 1):

- ensuring the competitiveness of enterprises and the economy;

- increasing the efficiency of the use of potential; facilities;
- formation of strategic development zones (by type of free economic zone in Navoi city, Kokand city, etc.);

- equalization of interregional inequalities;

- development of interaction at the level of countries and regions.

Institutional conditions are differentiated depending on the level of consideration: the lowest level - local, with the growth of the scale of influence - municipal and regional, the highest level - national. Depending on the degree of development and functioning, institutional conditions are subdivided by significance level for large, medium and small.

In the work of Corresponding Member of the Russian Academy of Sciences, Doctor of economic sciences, Professor G.B. Kleiner, the concept of formation and transformation of institutional systems - groups interrelated institutions, functioning within the framework of socio-economic objects of various levels are being developed: from enterprises to the country as a whole. The author developed the theory of a systemic economy, according to which the economy is viewed as a creation, functioning, transformation and interaction of economic systems from the point of view of the processes. G.B. Kleiner showed, that the systemic economy is a generalization and development of neoclassical, institutional and evolutionary economic theory.

At the same time, the author emphasizes the evolution of the system of economic institutions, leads a set of indicators that allow to characterize each institution. To this review, his proposed criterion is the type of subjects to be covered by the data of institutional condition. These include citizens, organizations, legal entities, employees of the enterprise, regions of the republic, etc[32].

Turning to the consideration of the small business itself, a set of factors (including noninstitutional ones) that are more influential on its activity will be presented as follows:

1. state of the economy and market conditions;

2. the importance of the relevant infrastructure;

3 . the policy of the state in relation to small business;

4. the influence of the social environment. 


\begin{tabular}{|c|c|c|c|c|c|c|}
\hline Impact Factor: & $\begin{array}{l}\text { ISRA (India) } \\
\text { ISI (Dubai, UAE } \\
\text { GIF (Australia) } \\
\text { JIF }\end{array}$ & $\begin{array}{r}=1.344 \\
=0.829 \\
=0.564 \\
=1.500\end{array}$ & $\begin{array}{l}\text { SIS (USA) } \\
\text { PИНЦ (Russia) } \\
\text { ESJI (KZ) } \\
\text { SJIF (Morocco) }\end{array}$ & $\begin{array}{l}=0.912 \\
=0.156 \\
=4.102 \\
=2.031\end{array}$ & $\begin{array}{l}\text { ICV (Poland) } \\
\text { PIF (India) } \\
\text { IBI (India) }\end{array}$ & $\begin{array}{l}=6.630 \\
=1.940 \\
=4.260\end{array}$ \\
\hline
\end{tabular}

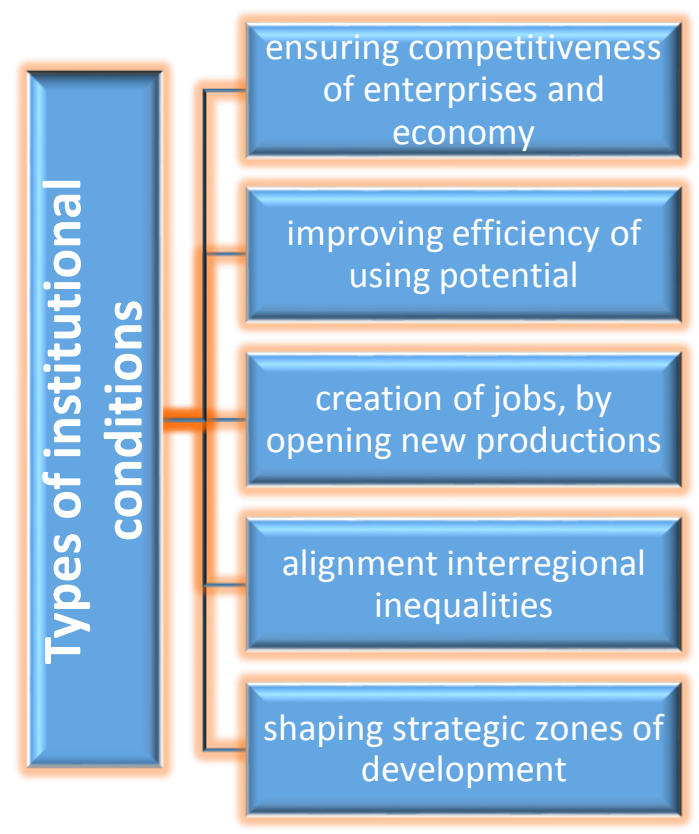

Fig.1. Types of institutional conditions.

The first group of factors is the state of the economy and the conjuncture. It is known that the development of the economy is characterized by cycle - the rise are replaced by recessions, the crises are revitalization, which has an impact not only on the economy as a whole, but also on the position of small entrepreneurs. Scientists do not observe a single point of view about the period in which the cycle is small business has the most favourable ground for its development. Some of them stand on the position that the largest surge of small business accounts for the periods of economic recovery and rise. The growth of production, income and wages, an increase in demand, and together with their prices and offers of goods occurs during this period. Expansion of the market provided favourable conditions, there are niches for small businesses. Another part of economists believe that there is a potential in a small business that facilitates the periods of recessions and even crises. During this period, production and a lot of businesses are bankrupt, experiencing a significant underload of production capacity, large enterprises have to resort to reducing the staff of their employees. The result os similar tendencies are growth of tension in the labour market. For most people creating their own business is the only an exit from the situation. As a rule, these are small firms from the owner and his family, so they stop their activity when the owner finds a job.

The carried out researches allow the author to allocate the first position.

The question studied was formulated in such a way that the first issue is not the number of newly created entities in this sector, but the dynamics of its development.

From this we can conclude that the infrastructure for supporting small businesses should include three main components (Fig. 2). 


\begin{tabular}{|c|c|c|c|c|c|c|}
\hline Impact Factor: & $\begin{array}{l}\text { ISRA (India) } \\
\text { ISI (Dubai, UAE } \\
\text { GIF (Australia) } \\
\text { JIF }\end{array}$ & $\begin{array}{r}=1.344 \\
=0.829 \\
=0.564 \\
=1.500\end{array}$ & $\begin{array}{l}\text { SIS (USA) } \\
\text { PИНЦ (Russia) } \\
\text { ESJI (KZ) } \\
\text { SJIF (Morocco) }\end{array}$ & $\begin{array}{l}=0.912 \\
=0.156 \\
=4.102 \\
=2.031\end{array}$ & $\begin{array}{l}\text { ICV (Poland) } \\
\text { PIF (India) } \\
\text { IBI (India) }\end{array}$ & $\begin{array}{l}=6.630 \\
=1.940 \\
=4.260\end{array}$ \\
\hline
\end{tabular}

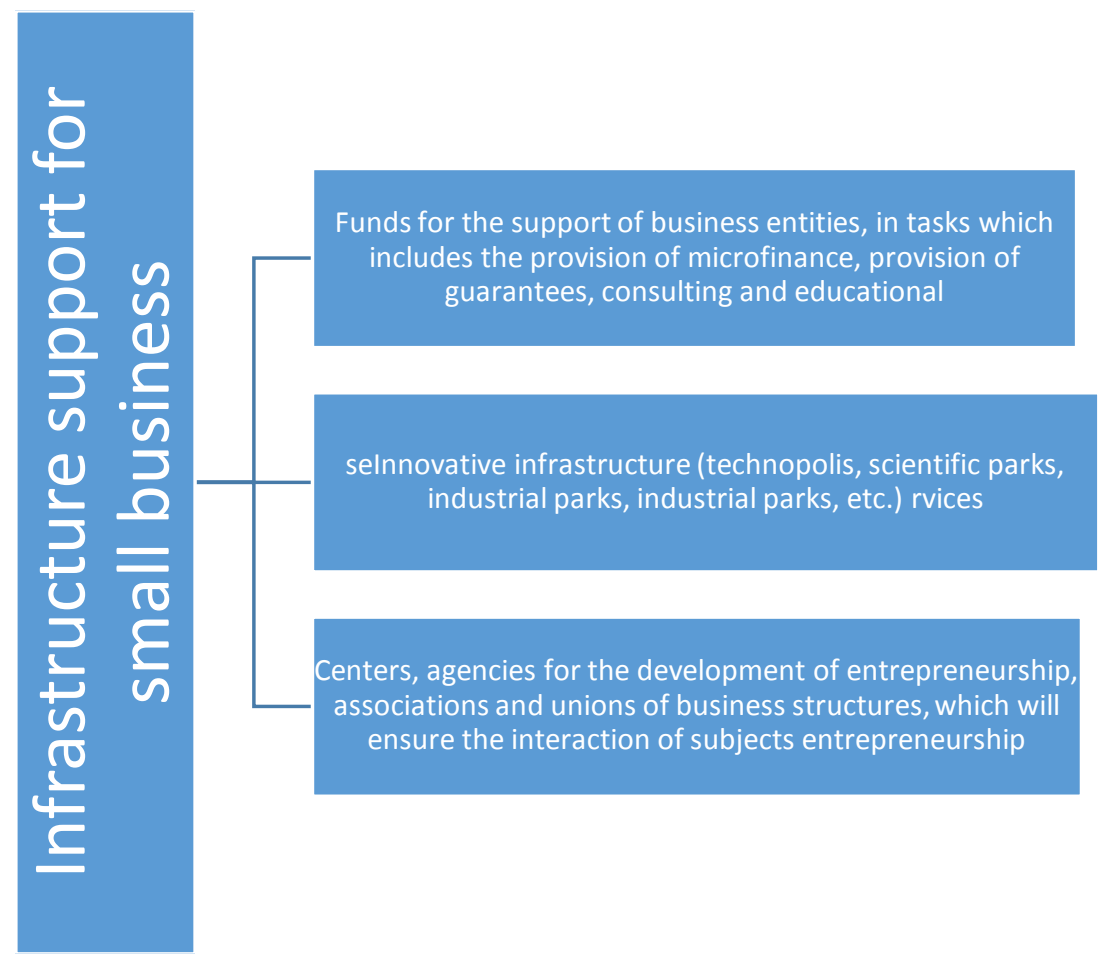

Fig.2. Small Business Support Infrastructure

Together, this makes for a small business the infrastructure that contributes to the development of this sector of the economy. The third group of factors is connected with the state regulation of this sector. State support plays an important role in its present and future. It can both contribute to and hinder its strengthening. Participation in the life of small business is carried out through ensuring favorable conditions for the development of small business. It may be: ease of reporting, tax benefits, security state orders, reduction of the working shift. Respectively absolutely opposite will be the conditions for a negative attitude of the government.

A similar range of issues, but somewhat differently, is explored in the work of analysts of the United States Agency for International Development, devoted to support of small business in the CIS countries [33]. So, Western scientists define the external environment of a small enterprise as a set of elements (markets, market institutions, processes, relations), directly influencing the formation and functioning small business. Five groups are identified that include elements of this environment:

- $\quad$ Resource and sales markets, being key to small business, are included in the first group;

- the second group includes the most important for small business market institutions and agents, in the role of which is a big business;

- Blocks of public organizations: legal, socio-cultural, political, expressed, respectively, in legislation, traditions and norms of morality, the alignment of political forces constitute the third group;

- $\quad$ in the fourth group, socio-economic processes and phenomena, such as crime, ecology, scientific and technical progress, the structure of the country's economy;

- The fifth group is a small business support system.

\section{Conclusions and offers}

The foregoing allows us to conclude that in two approaches there is a similarity, but their difference is of particular interest to the author, as for the researcher of the small business sector. Factors of external environment, indicated in the first approach, affect not only the small, but also the large business, even the entire economy of the country. The advantage of the second approach is that the specification of these factors allows one to see directly on the characteristics of the smallest business[30]. They are the following: the location of resource and distribution markets, informal relations with a narrow range of suppliers. Thus, the study of modern entrepreneurship with the use of an institutional approach is promising direction in economic science. Institutional theory allows identify the underlying, essential changes that contribute to the emergence of entrepreneurship in the country. The role of institutions is to provide entrepreneurs with the best opportunities to create a new enterprises, as well as create favourable conditions 


\begin{tabular}{|c|c|c|c|c|c|c|}
\hline Impact Factor: & $\begin{array}{l}\text { ISRA (India) } \\
\text { ISI (Dubai, UAE } \\
\text { GIF (Australia) } \\
\text { JIF }\end{array}$ & $\begin{array}{l}=1.344 \\
=0.829 \\
=0.564 \\
=1.500\end{array}$ & $\begin{array}{l}\text { SIS (USA) } \\
\text { PИНЦ (Russia) } \\
\text { ESJI (KZ) } \\
\text { SJIF (Morocco) }\end{array}$ & $\begin{array}{l}=0.912 \\
=\mathbf{0 . 1 5 6} \\
=\mathbf{4 . 1 0 2} \\
=\mathbf{2 . 0 3 1}\end{array}$ & $\begin{array}{l}\text { ICV (Poland) } \\
\text { PIF (India) } \\
\text { IBI (India) }\end{array}$ & $\begin{array}{l}=6.630 \\
=1.940 \\
=4.260\end{array}$ \\
\hline
\end{tabular}

for its further functioning and development. Institutional environment establishes rules of games understandable to all business entities, and forms the necessary conditions and incentives for business. Institutional environment has a significant impact on speed, nature and aspiration of individuals to business activities, providing direct and indirect impact on their behaviour.

At present, the formation of institutional conditions for free enterprise is understood as development. In our opinion, this process should be activated, carried out in line with[34]:

- optimization of the functioning of legal institutions with the help of elimination of duplicative and unnecessary laws, that is, simplification;
- decentralization - the transfer of administrative and legislative regional offices in order to bring local authorities to the real life and pressing problems of the entrepreneurship;

- $\quad$ expansion of the responsibilities and opportunities of individuals, for means of deregulation.

Thus, the formation of a clear representation of realistic existing system of institutional conditions, will determine, in implementation of the Strategy of Action for the five priority areas of development of the Republic of Uzbekistan within the period from 2017 to 2021 [35], the vector of institutional transformations for the coming years.

\section{References:}

1. Volchik V. V. (2012) State regulation of entrepreneurial of activities: the problem of institutional barriers // Journal of Economic Regulation (Issues of economic regulation). 2012. - T. 3. - No. 3.

2. Galbraith D. (1999) Economic policy is measured by the results // Problems of theory and practice of management. - 1999. - No. 5. P. 32-37.

3. Deakins D., Freel M.S. (2009) Entrepreneurship and small firms. - McGraw-Hill College, 2009.

4. Drucker PF (2007) Business and Innovation. Williams, 2007.

5. Marshall A. (1993) Principles of economic science. - // M .: Progress. - 1993. - T. 1. - P. 416.

6. Smith A. (1962) Research on the nature and causes of the wealth of peoples. - M .: Sotsakziz, 1962. - 684 p.

7. Santo B. (1990) Philosophy of Entrepreneurship // Problems of Theory and management practices. - 1990. - No. 3. - P. 96-101.

8. Tateisi K. (1992) The Eternal Spirit of Entrepreneurship // K.: Ukrzakordonvizaservis. - 1992.

9. (1993) Course of Entrepreneurship: Practical Manual / Per from Eng. - M .: International Relations, 1993.

10. Schumpeter J., Mileikovsky AG, Bomkin VI (1982) Theory economic development: (Study of entrepreneurial profit, capital, credit, interest and the cycle of conjuncture). with him. Progress, 1982.
11. Abalkin LI (2007) Notes on Russian Entrepreneurship / Selected Works: In 4 vols. t. T. III // VEO Rossii.-M : OAO "NPO Ekonomiki", 2000.-365-436p. - 2007.

12. Avtonomov V. (1997) Practice through the eyes of theorists (phenomenon entrepreneurship in economic theory) // Entrepreneurship in Russia. - 1997. - No. 4. - P. 5-11.

13. Blinov AO (2003) State and Entrepreneurship (Theory of the Mean class) // M .: Paleotypes. 2003.

14. Koichuev T., Koichueva M. (2001) Theory and practice of economic development in the Transition Period // Reform, Bishkek. - 2001.

15. Krivoruchko ON, Zaitsev AA, Lobanov SN (2000) Formation entrepreneurial economy in Russia. - Moscow: The Economy, 2000.

16. Lapusta MG, Starostin Yu. L. (2005) Small business. - Infra-M, 2005.

17. Orlov AK (2015) Features of investment evaluation of development megaprojects with the participation of the state // Economics and Entrepreneurship. - 2015. - No. 5-1. - P. 892895.

18. Primov E. (2003) Formation and development of entrepreneurial activity in the Kyrgyz Republic // Society and Economics. - 2003. No. 9. - P. 127-134.

19. Rube V. (2017) Institutional Aspects of Small Business Organization in developed countries and in Russia. Tutorial. - Litres, 2017.

20. Shamkhalov F. (2011) Small business in the system of market Reforms: Problems of Growth 


\begin{tabular}{l|lr|ll|ll} 
& ISRA (India) & $=\mathbf{1 . 3 4 4}$ & SIS (USA) & $=\mathbf{0 . 9 1 2}$ & ICV (Poland) & $=\mathbf{6 . 6 3 0}$ \\
Impact Factor: & ISI (Dubai, UAE) $=\mathbf{0 . 8 2 9}$ & PUHЦ (Russia) $=\mathbf{0 . 1 5 6}$ & PIF (India) & $=\mathbf{1 . 9 4 0}$ \\
& GIF (Australia) & $\mathbf{0 . 5 6 4}$ & ESJI (KZ) & $=4.102$ & IBI (India) & $=\mathbf{4 . 2 6 0}$ \\
& JIF & $=\mathbf{1 . 5 0 0}$ & SJIF (Morocco) & $=2.031$ & & \\
\hline
\end{tabular}

or Survival // Issues of Economics. - 2011. - T. 10.

21. Yudanov A. Yu. (2010) Entrepreneurs of entrepreneurship: gazelle firms in Russia // Journal of the New Economic Association. 2010. - No. 5. - P. 91-108.

22. Khikmatov A., Trostiansky D. (2002) Development of small business as a factor of economic growth in Uzbekistan // Society and economy. - 2002. - No. 2. - P. 142-148.

23. Ikramov M.A. (2013) Some issues of state regulations innovation process: foreign experience and practice of Uzbekistan// Innovative economy: prospects for development and improvement. - 2013. - No. 3. - P. 198-205.

24. (2016) Collection of legislation of the Republic of Uzbekistan, 2016, No. 40, art. 467.

25. (2017) Measures to radically improve the system of state protection of legitimate business interests and further development entrepreneurial activity. Decree of the President of the Republic of Uzbekistan N UP-5087 dated June 19, 2017 // Collection of Legislation of the Republic Uzbekistan, June 27, 2017, No. 25, art. 522.

26. (2017) On improving the organization of the Chamber of Commerce and Industry of the Republic of Uzbekistan. Resolution of the President Republic of Uzbekistan No. PP-3068 dated June 19, 2017, // Collection legislation of the Republic of Uzbekistan, 2017, No. 26, art. 578).

27. (2017) The economy of Uzbekistan. Information and analytical bulletin for JanuaryDecember of 2016. - Tashkent, CER, 2017.
28. North D.C. (2012) economic performance through time // Revista Universidade AFIT. 2012. - T. 30. - No. 93. - P. 9-18.

29. Yudenko MN, et al. (2008) Problematic issues of institutional development theory of entrepreneurship // Vestnik NSU: a series of socio-economic science. - 2008. - T. 8. - No. 3. - P. 80-87.

30. Kalantaridis C., Fletcher D. (2012) Entrepreneurship and institutional change: Are search agenda // Entrepreneurship \& Regional Development. - 2012. - T. 24. - No. 3-4. - P. 199-214.

31. McCarthy B. (2012) From fishing and factories to cultural tourism: The role of social entrepreneurs in the construction of a new institutional field // Entrepreneurship \& Regional Development. - 2012. - T. 24. - No. 34. - P. 259-282.

32. Kleiner G.B. (2004) The evolution of institutional systems. - Moscow: Nauka, 2004.

33. (2018) Available: https://www.usaid.gov/ (Accessed: 10.08.2018).

34. Kurpayanidi K. (2015) Innovation component of the business environment as a factor enhancing economic growth //Economics. 2015. - №. 1. - C. 6-9.

35. (2017) On the strategy for action for the further development of the Republic Uzbekistan. Decree of the President of the Republic of Uzbekistan No. UP-4947 of February 7 2017, // Collection of Legislation of the Republic of Uzbekistan, 2017, No. 6, art. 70, No. 20, art. 354 , No. 23 , art. 448, No. 29 , art. 683 , art. 685 , No. 34 , art. 874 